\title{
The Unified Patent Court and the Transformation of the European Patent System
}

\author{
Aurora Plomer
}

Published online: 23 July 2020

(C) Max Planck Institute for Innovation and Competition, Munich 2020

Harmonisation of the European patent system was singled out by the Council of Europe in 1949 as one of the three top priorities for the reconstruction of Europe at the end of WWII. The latest setback in the German Constitutional Court in case No. BvR 739/17 and the challenges posed by Brexit to the future of the Unified Patent Court are characteristic of a project whose realisation has proved stubbornly difficult for historical and structural reasons. Legal uncertainty and doubts are poised to persist even if the voting requirements for ratification in Germany are met. The reasons are fourfold.

First, the Unified Patent Court Agreement (UPCA) is a uniquely complex Treaty, straddling across international, European Union and national laws, creating an unprecedented "international" court also defined as a common court of the Member States (Art. 1) under an obligation to apply European Union law in its entirety (Art. 24(1)(a)). It has exclusive jurisdiction (Art. 32) for the enforcement of "European Patents with Unitary Effect" (EUPE), created by EU legislation but granted and administered by the EPO (Regulation (EU) No. 1257/2012, Art. 9), and it is an autonomous international organisation outside the European Union. Inevitably, the grey areas and inherent tensions in this legal scaffold are extensive and well documented. To single out some pressing questions, as the UPCA does not specify the conditions and applicable law for a Member's continuing participation upon leaving the EU or its withdrawal from the UPCA, ${ }^{1}$ it is unclear whether this is to be determined by reference to the Vienna Convention on the Law of Treaties and/or

\footnotetext{
1 As announced by the UK to the media blog IAM https://www.iam-media.com/law-policy/uk-no-upc. For comments on whether the UPC is being used as a bargaining chip by the UK in the Brexit negotiations see http://patentblog.kluweriplaw.com/2020/03/03/uk-backs-out-of-the-unitary-patent-system-ablow-the-end-of-it-or-just-tactics/?doing_wp_cron=1594117050.5273120403289794921875.
}

A. Plomer $(\bowtie)$

Professor of Intellectual Property and Human Rights

School of Law, University of Bristol, Bristol, UK

e-mail: a.plomer@bristol.ac.uk 
European Union Law, notably the CJEU's Opinion 1/09 which declared the UPC's predecessor incompatible with the Treaties. Detailed legal analyses on the possibility of the UK's continuing participation post-Brexit and the economic value of the UPC without the UK have come to different conclusions. ${ }^{2}$

Secondly, the purpose of European patent integration is to facilitate completion of the establishment of a single market (Art. 3(3) TEU), but the UPCA defeats that purpose by formally fracturing the EU market between the 25 participating States (currently still including the UK) and the non-participating States (Spain, Poland and Croatia) as well as (possibly) the States which originally signed but have not ratified the Treaty (presently a total of eight). ${ }^{3}$ The original economic rationale goes back to the creation of the European Economic Community in 1957, founded on a liberal economic vision which attributed the depression of the 1930s to trade barriers and protectionist tariffs driven by narrow national interests. In pursuit of this ideal, the EEC created "an ever closer union" between the six original States and citizens, with a common market for the free movement of people, goods, services and capital to promote economic and social development through the elimination of barriers to trade (Art. 3, EEC 1957). Harmonisation of the European patent system has thus been integral to the liberal economic vision of facilitating cross-border investment with the creation of a simple and cost-effective system for applicants across the whole Europe. But by the time the European Community was founded in 1957 (without the UK's participation), the patent unification project had already been underway at the Council of Europe for almost ten years. ${ }^{4}$ The project was then pursued in parallel lines by the Council of Europe and European Community, the latter being held back by the absence of a clear legal basis for patent unification in the Treaties as a measure which had a direct impact on the functioning of the internal market under Art. 100. It was not until the Treaty of Lisbon (2007) that competence was expressly conferred on the Union in Art. 118 TFEU (2008/C 115/01) - albeit in qualified terms. Article 118 mandates the Council and Parliament "to establish measures for the creation of European intellectual property rights to provide uniform protection of intellectual property rights throughout the Union and for the setting up of centralised Union-wide authorisation, coordination and supervision arrangements." In Spain v. Council, the CJEU dismissed Spain's complaint that, in the absence of unanimity, the "patentpackage" (EU Unitary Patent created by EU Regulations and Unified Patent Court created by the UPCA) was incompatible with the Treaties on the grounds that Art.

\footnotetext{
${ }^{2}$ See for instance R. Gordon, T. Pascoe, (2017), "Re the Effect of 'Brexit' on the Unitary Patent Regulation and the Unified Patent Court Agreement", Opinion commissioned by the IP Federation, the Chartered Institute of Patent Attorneys and the Intellectual Property Lawyers Association, 12 September 2016; Matthias Lamping and Hanns Ullrich (2018), "The impact of Brexit on unitary patent protection and its court." in: Max Planck Institute for Innovation \& Competition Research Paper pp. 18-20; Thomas Jaeger (2017), "Reset and Go: The Unitary Patent System Post-Brexit" IIC 48(3):254-285, https://doi. org/10.1007/s40319-017-0569-y; Winfried Tilmann (2020), "The UPC without the UK: Consequences and Alternatives" GRUR International https://doi.org/10.1093/grurint/ikaa076.

${ }^{3}$ Ratification status: https://www.consilium.europa.eu/en/documents-publications/treaties-agreements/ agreement $/$ id $=2013001 \&$ DocLanguage $=$ en .

${ }^{4}$ Aurora Plomer (2015), "A unitary patent for a (Dis) United Europe: the Long Shadow of History." IIC 46(5):508-533, https://doi.org/10.1007/s40319-015-0356-6.
} 
118 and Art. 262 TFEU did not predetermine any particular structure. ${ }^{5}$ The analysis of the German Constitutional Court (GCC) in BvR 739/17 offers a different perspective. According to the GCC, the legal basis for Art. 118 should have been Art. 262 TFEU or 48 TEU, which require unanimity. As unanimity could not be secured, Council Members were unable to transfer jurisdiction from national courts to the CJEU under Art. 262 TFEU or 48 TEU, so members "changed the integration programme of Lisbon and chose a functional alternative to 'a proper Union court' alongside the EU". 6 In the GCC's view, the creation of the UPC “... constitutes an amendment or replacement of Article 262 TFEU (para. 154)". For this reason, the GCC concluded that the reallocation of judicial functions superseding German courts constituted an amendment to the German constitution in substantive terms, which requires a 2/3 majority vote in parliament. The GCC left open the question of whether the primacy of EU law in Art. 20 (UPCA) complies with the German Basic Law. ${ }^{7}$

The fact that the GCC opted not to make a referral to the CJEU, as requested by the applicant, does not preclude a future request for a preliminary ruling. A referral is possible on the question of whether the designation of the UPC as a "court common to the Member States" with the same obligations as national courts vis-àvis EU law (Art. 1 UPCA) is equivalent to an extension of "the jurisdiction of European Union courts ..." sufficient to guarantee the uniform application of EU law in accordance with Opinion 1/09 (para. 62). ${ }^{8}$ Moreover, the GCC's analysis in the European Central Bank case ${ }^{9}$ suggests that the creation of the Unified Patent Court could be the type of decision that would require the application of objective methodological standards by the CJEU, in cooperation with national courts, to safeguard the division of competences in the Treaties. ${ }^{10}$ In the event of a referral, whether the UPC could begin to function pending a decision from the CJEU is a moot question, evidencing one of the many legal gaps left in the complex interlocking of the UPCA, EU law and national laws.

\footnotetext{
5 EU:C: 2013:240, para. 88.

6 Case No. BvR 739/17, para. 145, emphasis added.

7 This was left open by the Court in the light of its finding that the ratification bill had not been passed with a 2/3 majority (ref). The review would be further facilitated by the GCC's construction of the UPCA as a Treaty which is complementary to and in special relationship of proximity with the EU. (para. 132), paras 144, 145, 146, 147 ("close interlocking"), 148, 149, 150.

8 In Art. 1/09 [2011] ECR I-1137, the CJEU stated that "Article 262 TFEU provides for the option of extending the jurisdiction of the European Union courts to disputes relating to the application of acts of the European Union which create European intellectual property rights. Consequently, that article does not establish a monopoly for the Court in the field concerned and does not predetermine the choice of judicial structure which may be established for disputes between individuals relating to intellectual property rights."

9 BvR 859/15, 2 BvR 980/16, 2 BvR 2006/15, 2 BvR 1651/15.

${ }^{10}$ It is imperative that the judicial mandate be exercised in a coordinated manner to respect respective mandates - Precedence and uniform application of EU law would otherwise be undermined HOWEVER - Member states remain "the masters of the treaties" as the EU has not evolved into a Federal State. They retain a residual power of review - in exceptional circumstances - where, for instance the EU adopts a legal interpretation that would essentially amount to a treaty amendment or an expansion of its competences. BVerfGE 123, 267, 370 and 371.
} 
Thirdly, in the event that the UPCA does enter into force, ${ }^{11}$ other questions of substance which could be the subject of preliminary requests relate to whether the UPCA's structure can secure adequate protection of fundamental rights. The UPCA confers on the UPC powers to produce evidence, seize goods and inspect premises (Arts. 59 and 60) which, as noted by the GCC in BVR 739/17, constitute an "encroachment of fundamental rights" in the territories of Member States (at para. 158). The potential far-reaching impact of IP enforcement measures on public health, privacy and individuals rights of access to courts have prompted concern in academic publications, particularly in relation to alleged infringements of pharmaceuticals by manufacturers of generics, which led the EU Parliament to overwhelmingly reject EU ratification of an international agreement criminalising infringements of intellectual property. ${ }^{12}$ Under the UPCA, remedies will be civil rather than criminal, but orders, injunctions, seizures and awards against defendants will still need to be compliant with the protection of fundamental rights in the EU Charter, notably rights to privacy (Art. 7), personal data (Art. 8), health (Art. 35), good administration (Art. 41), access to documents (Art. 42), justice, fair trial (47), presumption of innocence (48), and legality and proportionality of criminal offences and penalties (49). These rights are derived from Arts. 6 and 8 of the European Convention on Human Rights, which Member States of the European Union are under a separate obligation to protect and in respect of which they remain separately liable. The ECHR is not mentioned in the UPCA, and the Charter is only mentioned in the Preamble of the UPCA. It is not expressly listed in the binding part of the agreement in Art. 24 detailing the applicable sources of law. It may, of course, be argued that the Charter (and more problematically the ECHR) is implicitly contained in Art. 24(1)(a). But it is at least questionable whether adequate weight is given to the UPC court's obligation to protect fundamental rights in the issuing of far reaching orders in the absence of express requirements to this effect. The onus would likely lie on individuals defending infringement proceedings which they believe violate their fundamental rights to require the UPC to make a preliminary reference to the CJEU. The time and costs involved would, in all likelihood, cause significant or even irreparable harm to applicants. In the event that the UPC declines to make a referral or issues an order inconsistent with the EU Charter or the ECHR, there would be no avenues for appeal.

Finally, the UPCA entrenches the systemic fragmentation of the European patent system created by the European Patent Convention. The EPC was set up in 1973 outside the EEC, as an autonomous international organisation with an administrative office (EPO) charged with the task of applying the "common law" of the participating European States. The EPC was originally adopted as a temporary

\footnotetext{
11 http://patentblog.kluweriplaw.com/2020/06/22/period-of-provisional-application-unified-patent-courtagreement-can-start-this-year/?doing_wp_cron=1593683284.5808699131011962890625.

12 See D. Matthews and P. Zikovska (2013), The Rise and Fall of the Anti-Counterfeiting Trade Agreement (ACTA): Lessons for the European Union, IIC 44:626, https://doi.org/10.1007/s40319-0130081-y; and Thomas Jaeger "Merging ACTA into TRIPS: Does TRIPS-Based IP Enforcement Need Reform?" in: Hanns Ullrich, Reto M. Hilty, Matthias Lamping, and Josef Drexl (eds) Trips-plus 20, Springer; Henning Grosse Ruse-Khan, (2010) "A Trade Agreement Creating Barriers to International Trade: ACTA Border Measures and Goods in Transit” Am. U. Int'l L. Rev. 26:645.
} 
measure pending the full harmonisation of the administration and enforcement of patents within the EEC. It has since proved stubbornly resistant to integration within the EU legal order, whilst implementing EU law (notably the Biotech Directive). The EPO has morphed over time into a quasi-judicial body through its interpretation and extension of the general, abstract eligibility requirements of patentability (novelty, inventive step and industrial application) and patent exclusions (stem cells, plants, computer programs). ${ }^{13}$ The majority of patents granted by the EPO are to companies outside Europe. ${ }^{14}$ Yet, the EPO will remain out with the Union's legal order and its function will be enhanced by the UPCA, as the administrator of the unitary patent.

In the long run, the UPC's future and sustainability is dependent upon the constitutional and political stability of the European Union which has yet to find a new equilibrium in the wake of Brexit. ${ }^{15}$ EU lawyers have characterised the dynamics between the EU court and constitutional national courts as a plural dialogue, multi-level governance, constitutional plurality, etc. ${ }^{16}$ Whichever, even if judicial cooperation and harmony are restored following German ratification of the UPC, as suggested by Weiler in his prescient article of $1992,{ }^{17}$ judicial power in the EU ultimately flows back to acquiescence from the Member States. In relation to the UPC this means that the new, centralised court and unitary patent must be perceived as conferring economic benefits not only to applicants but to the (citizens of the) participating States too. We know from the troubled history of the EU that the required unanimity under Art. 118 of the Lisbon Treaty, could not be secured because a minority of Member States were not convinced of the economic benefits that were presumed to flow to them. Concerns that unitary patents might drive out local industries in less-advanced economies in the EU had been voiced as early as the 1970s, well before the accession of former communist countries. Since then, a report by Deloitte for the Polish government in 1992 estimated that the Polish economy would suffer by some 19 billion euros in 30 years if the country participated in the Unitary Patent system. The possibility of a similar fate in the Czech Republic was noted in a commissioned report by PWC which identified possible interferences with the ability and rights of SMEs/individuals to defend

\footnotetext{
13 Aurora Plomer (2019) "The EPO as patent law-maker in Europe." European Law Journal 25(1):57-74.

14 The last published figures are for 2018. The analysis shows that the majority of companies were granted to companies from the US (24\%), Japan (17\%), China (4\%), Korea (5\%) and others (5\%). https:// www.epo.org/about-us/annual-reports-statistics/annual-report/2018/statistics/granted-patents.html. The statistics published by WIPO for 2019 show a similar trend worldwide: "China's Huawei Technology remained the top filer of the PCT international applications in 2019. It was followed by Mitsubishi Electric of Japan, Samsung Electronics from the Republic of Korea, Qualcomm of the US, and Oppo Mobile Telecommunications of China. Among the top ten users, seven are located in the North East Asia." https://www.wipo.int/edocs/infogdocs/en/ipfactsandfigures2019/.

15 In the immediate future, it is unclear how the financial gap left by the UK's departure from the UPCA will be filled.

16 Matej Avbelj and Jan Komárek (eds.) (2012), Constitutional pluralism in the European Union and beyond Bloomsbury Publishing.

17 Joseph HH Weiler, (1991) “The transformation of Europe." Yale Law Journal pp. 2403-2483.
} 
infringement actions. ${ }^{18}$ Similar fears have been voiced by software companies in the $\mathrm{UK}^{19}$ and by patent judges concerned that the UPC has “... the potential to favour patentees and to increase the cost and complexity of patent litigation. Should that prove the case, it might stifle innovation and competition and even drive manufacturing businesses out of the EU". ${ }^{20}$

Everyone agrees that simplification of the European patent system would be welcome. The difficulty lies in designing a streamlined court structure which is accessible and fair to patentees whilst encouraging and supporting European innovation. The UPC is not such a court. It adds another judicial layer alongside the EU and national courts, and it exacerbates the existing fragmentation. The risk is that the likely beneficiaries of the unitary patent and UPC will be transnational corporations outside Europe. The likely casualties will be European SMEs at the forefront of European innovation as targets of infringement suits without the resources to navigate an inherently uncertain and overwhelmingly complex legal territory.

Publisher's Note Springer Nature remains neutral with regard to jurisdictional claims in published maps and institutional affiliations.

\footnotetext{
${ }^{18}$ http://patentblog.kluweriplaw.com/2019/09/13/legal-and-financial-concerns-czech-republic-will-notratify-upca-any-time-soon/?doing_wp_cron=1593438499.3551509380340576171875.

$19 \mathrm{http}: / /$ www.nounitarysoftwarepatents.uk/uk-software-companies-oppose-unitary-patent-ratification.

${ }^{20}$ Sir David Kitchin in: Pila and Wadlow (eds.) (2015), The Unitary EU Patent System, Bloomsbury Publishing, p. 8.
} 